\title{
Econometric Modeling of Turkish Participatory Banks Deposits
}

\author{
Hüseyin Çetin
}

\begin{abstract}
That article is about the financial parameters relationship with Turkish participatory banks deposits. Those financial parameters are 3 Month London Libor rates, 1 Ounce London Gold Prices and Turkey's Customer Price Index data. First lag value of Turkish participatory banks total deposits has significant impact on Turkish participatory banks deposits. It was found that none of the financial parameters have significant effect on Turkish participatory banks deposits between the monthly data of December 2005-November 2013. Nevertheless, according to Johansen cointegration test, there is long term relationship between all variables. Comparative performance analysis of 3 Month London Libor rates and Customer Price Index data has been done. By implementing Granger causality analysis, impulse response analysis and variance decomposition analysis and vector error correction model, it was found that Libor3M rates are more successful than Turkey's Customer Price Index data and 1 Ounce London gold prices for evaluating the change of Turkish participatory banks deposits. According to vector error correction model, 3 month Libor rates have negative adjustment effect on Turkish participatory banks deposits. Turkey's Customer Price Index rates do not have negative adjustment effect on Turkish participatory banks deposits.
\end{abstract}

Index Terms-First lag value of Turkish participatory banks deposits, 3 Month Libor rates, London gold prices, Turkish participatory banks deposits, customer price index, PLS.

\section{INTRODUCTION}

Banks indispensable function is to collect deposits from households, firms and use those deposits for businesses and household necessity. Islamic banks mainly collect deposit from customers, business and use those deposits for business developments such as providing credit for factory machines. Participatory banks do not ensure credit directly for interest rate profits and participate in Profit-Loss transactions (PLS). Between the years of 2003-2013, Turkey's participatory banks deposits have been increasing fast. Due to the globalization process and systematic risks, Turkish participatory banks like conventional banks strongly influenced by financial systematic risk processes.

Islamic banking refers to a system of banking or banking activity that is consistent with Islamic law principles and guided by Islamic economics [1]. Islamic banking has emerged as a mainstream alternative to conventional finance in a growing number of countries [2]. Along with the global expansion of conventional modes of financing, the Islamic banking industry has grown significantly since its inception in the early 1970's and moved beyond the confines of a niche

Manuscript received March 20, 2014; revised May 19, 2014.

Hüseyin Çetin is with the Okan University, Social Science Institute, Istanbul, Turkey (e-mail: h_cetin86@ hotmail.com). market, largely due to the greater financial liberalization and unprecented inflow of petrodollars to the Middle East [3].

The performance of 265 Islamic equity funds from 20 countries using monthly returns calculated from data between September 1990 and the end of April 2009 was analyzed. It was found that the performance of Islamic funds in countries with relatively more developed Islamic markets outperformed conventional benchmarks but underperformed them in the countries with less developed Islamic equity markets [4].

By some optimistic estimates, Islamic Banks could account for $50 \%$ of all savings in the Muslim world by 2010 [5].In 1999, Dow Jones created Islamic Indexes to offer Sharia complaint investment portfolios to cash flush pious Muslims. Several major Western Banks, e.g Citibank, ABN Amro, HSBC Standard Chartered and Union Bank of Switzerland, either have Islamic banking subsidiaries or offer Islamic financial products to customers. Clearly, Islamic banking and finance has transformed itself from an obscure financial experiment to major factor in global finance [6].

Islamic banks are better capitalized, have higher asset quality and are less likely to dismantle operations during crises compare to conventional banks. The better stock performance of listed Islamic banks during the recent crisis is also due to their higher capitalization and better asset quality [7].

Four variables will be used for analysis. Customer price indexes, 3 Month Libor rates and London gold prices will be independent variables and Turkish participatory banks deposits will be taken as dependent variable. The short term relationship and long term relationship between CPI, 3 Month Libor rates, 1 Ounce London gold prices and Turkish participatory banks deposits will be measured.

\section{LITERATURE REVIEW}

On the asset side, the balance sheets of Islamic banks have an implicit link to interest bearing instruments. In theory, the Islamic model of banking adheres to the principles of equity participation and risk sharing since Sharia-complaint banks derive their earnings from venture financing-type investments. While funding activities are mainly carried out through the participatory PLS model, it is well established in the literature that Islamic banks follow their conventional counterparts in creating assets through non-PLS, debt like instruments with a predetermined, fixed rate of return [2].

There are few differences in business orientation, efficiency, asset quality or stability between conventional and Islamic banks [8].

Financial market disruption and resultant devaluation of 
financial instruments affected the balance sheets of financial market players, which essentially became contagion channels [9].

Increased integration of financial industry has increased the contagion effect that is central to systematic risk [10].

All investors assume systematic risks, whenever assets owned or claims issued can change in value as a result of broad economic factors. As such systematic risk comes in many different forms. For the banking sector, however two of are greatest concern, namely variations in the general level of interest rates and the relative value of currencies [11].

In terms of macroeconomic variables, researchers have found a link between inflation, interest rates and profitability [12], [13] and as well as the business cycle and banking performance [14], [15].

Given the implict correlation to interest rates on the asset side of balance sheet, PLS returns follow conventional banks deposit rates. Such correlations have been unearthed in other studies [2].

In Malaysia, Islamic bank deposit rates have similar trend with conventional interest rates [16].

The response of the deposits and loans held at conventional and Islamic banks to interest rates of monthly data for the period between 2005: 12 and 2009: 07 were analyzed based on VAR methodology. The findings indicates that any change in the interest rates influences not only the deposits and loans of conventional banks but also such instruments of Islamic banks in Turkey [17].

Empirical analysis shows cointegration, causality and volatiliy correlation between conventional and retail Islamic bank returns. Based on the Johansen cointegration methodology, the rates of return on PLS accounts and conventional bank deposit rates found to be cointegrated in both Malaysia and Turkey. Moreover, in Malaysia and Turkey, conventional interest rates Granger cause the return of on Islamic investment accounts both in levels and first differences. PLS returns determined partly by conventional interest rates. Since the pairwise Granger causality test may produce misleading results when the true nature of the relationship involves a common third process, additional variables are introduced within a vector error correction model and confirm the unidirectional causal relationship from conventional interest rates to PLS return [2].

By using VECM model, it was found that PLS returns in Turkey are strongly influenced by conventional interest rates and, to a lesser extent, by customer price inflation [2].

In addition, time varying volatility pattern of conventional and Islamic bank deposit returns was investigated by using the rolling standard deviation and volatility correlation of two series and demonstrated that there was a high, and statistically significant correlation between the volatility of conventional interest rates and PLS returns in both Malaysia and Turkey [2].

\section{Methodology}

Data collected from secondary sources. 1 Ounce London gold prices (USD) data and Turkish participatory banks deposits data collected from Turkish Central Bank website (http://evds.tcmb.gov.tr/yeni/cbt-uk.html). In addition to that, Libor 3 Month rates data collected from St. Louis Fed website

(http://research.stlouisfed.org/fred2/series/USD3MTD156N/ downloaddata?cid=33003 ).

3 Month Libor rates are significant for financial borrowing process. In the USA, home loans and car loans significant influenced by Libor rates. Even some food prices in the world can be determined by libor rates. Libor rates are the fundamental interest rate tool for banking industries.

Data will be monthy basis. The time domain is December 2005-November 2013. Box-Cox transformation has been applied to Turkish participatory banks deposits, 1 ounce London gold prices (USD) and CPI rates.

BDS test measures whether the series are weak form efficient or not. Before implementing BDS test, series first difference was taken. After detrending the Turkish participatory banks total deposits, BDS test was used. Table I presents that Turkish participatory banks detrended total deposits are weak form efficient which means future deposits can be forecasted without structural breaks by historical values of Turkish participatory banks deposits.

First of all, by using linear regression, lagged Turkish participatory bank deposits effects on Turkish participatory banks deposit rates measured. Sequential elemination method applied. Since monthly data being used; lag threshold taken as 12 .

TABLE I: BDS TEST - CHANNELS BDS STATISTICS PROBABILITY

\begin{tabular}{|l|l|l|}
\hline 2 & 0.01 & 0.15 \\
\hline 3 & 0.02 & 0.07 \\
\hline 4 & 0.02 & 0.11 \\
\hline 5 & 0.03 & 0.09 \\
\hline
\end{tabular}

-Null hypotheses: Series are weak form efficient

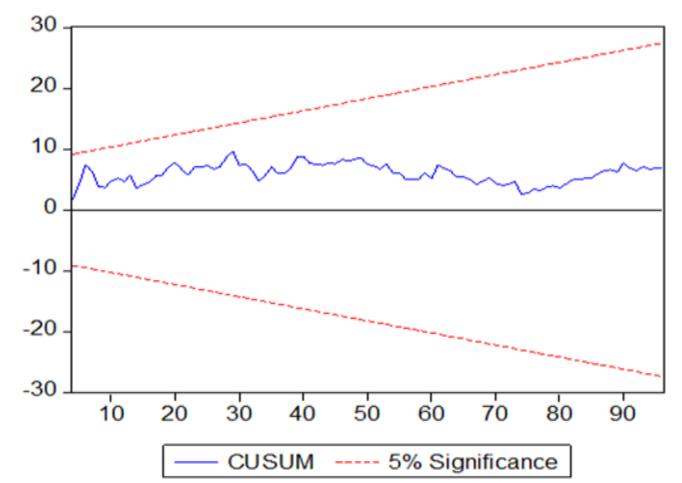

Fig. 1. Cusum graph.

Cusum test has been applied. Fig. 1 indicates that there is no structural break and no dummy variable will be used. In addition to that, Libor3M (-1 to -12$)$ were put into analysis. Libor3M(-2) and Gold(-7) had spurious significant effect on Turkish participatory banks deposits. Sequential elemination methods applied to those spurious significant variables. These variables again used with first lag of Turkish participatory banks deposit rates in linear regression analysis. At first process, Gold(-7) has lost its significance status then Libor3M(-2) has lost its significance status. Table II indicates that only first lag of Turkish participatory banks total deposit rates had significant impact on Turkish participatory banks 
deposits between the time interval of 2005 December-2013 November.

TABLE II: LINEAR REGRESSION TEST — P VALUE
\begin{tabular}{|l|l|}
\hline Constant & 0.08 \\
\hline Deposits(-1) & $0.00 *$ \\
\hline Deposits(-2) & 0.91 \\
\hline Deposits(-3) & 0.55 \\
\hline Deposits(-4) & 0.59 \\
\hline Deposits(-5) & 0.17 \\
\hline Deposits(-6) & 0.16 \\
\hline Deposits(-7) & 0.40 \\
\hline Deposits(-8) & 0.66 \\
\hline Deposits(-9) & 0.92 \\
\hline Deposits(-10) & 0.77 \\
\hline Deposits(-11) & 0.86 \\
\hline Deposits(-12) & 0.87 \\
\hline *indicates p value is less than 0.05
\end{tabular}

In addition, since there is high correlation between external variables, those variables can not be used together in linear regression analysis. AR(1) was used for fixing autocorrelation problem.@trend was used for to prevent spurious regression. It has been found that none of the variable has significant impact on Turkish participatory banks deposits for short term.

Before implementing Granger causality analysis for short term causal relation, Johansen cointegration analysis was conducted. All of the four variables are at same order. Their first differences taken by genr function. All series have unit root problem. In order to convert variables from $\mathrm{I}(0)$ to $\mathrm{I}(1)$ process genr function applied. After transformation, unit root problem resolved and data have stationary structure. In this article, except linear regression test, all of the econometrical methodologies were done with stationary data.

genr deposits $1=$ deposits-deposits $(-1)$

genr libor3m1=libor3m-libor3m(-1)

$$
\text { genr } \text { cpi1 }=\text { cpi-cpi }(-1)
$$

genr gold1= gold-gold $(-1)$

Vector Autoregression analysis has been done and lag length criteria tests conducted. Since data quantity is 96, Schwarz information criteria used. Table III indicates that Turkish participatory banks deposits, 3 Month Libor rates, London gold prices and Turkey's Customer Price Index data have long term equilibrium relationship.

TABLE III: JOHANSEN COINTEGRATION ANALYSIS - CHANNELS

\begin{tabular}{|l|l|l|}
\multicolumn{2}{l}{ EIGENVALUE PROBABILITY } \\
\hline None* & 0.606362 & 0.0001 \\
\hline At most ${ }^{*}$ & 0.503447 & 0.0001 \\
\hline At most2* & 0.44559 & 0.0000 \\
\hline At most3* & 0.179384 & 0.0000 \\
\hline
\end{tabular}

*indicates $\mathrm{p}$ value is less than 0.05
Variance decomposition analysis and impulse response analysis applied. Fig. 2 and Table IV result indicated that libor $3 \mathrm{~m} 1$ innovation impact is higher than other independent variables' innovation impact on Turkish participatory banks deposits variance rates.

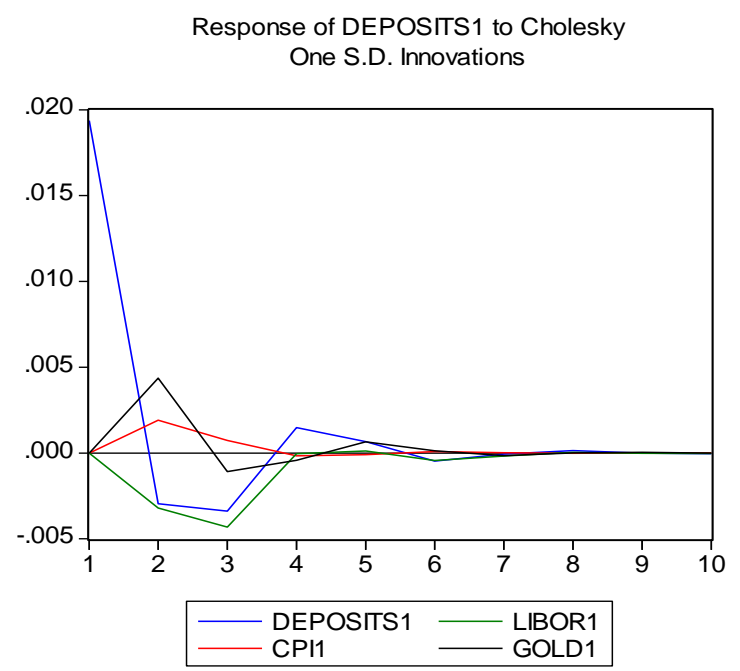

Fig. 2. Impulse response graph.

TABLE IV: VARIANCE DECOMPOSITION ANALYSIS — PERIOD DEPOSITS1 CPI1 GOLD1 LiBOR3M1

\begin{tabular}{|l|l|l|l|l|}
\hline 1 & 100 & 0 & 0 & 0 \\
\hline 2 & 89.03 & 0.77 & 7.41 & 2.71 \\
\hline 3 & 78.26 & 1.31 & 6.66 & 13.75 \\
\hline 4 & 66.91 & 11.02 & 8.71 & 13.33 \\
\hline 5 & 64.62 & 10.74 & 11.14 & 13.48 \\
\hline 6 & 63.52 & 10.73 & 10.75 & 14.97 \\
\hline 7 & 62.60 & 10.91 & 11.08 & 15.39 \\
\hline 8 & 59.88 & 11.55 & 12.28 & 16.27 \\
\hline 9 & 57.91 & 12.10 & 12.38 & 17.59 \\
\hline 10 & 56.45 & 12.64 & 12.82 & 18.07 \\
\hline
\end{tabular}

-Period indicates variance time

In addition to that, Granger causality has been done between lag 1 and lag 12. There are unidirectional relationships between stationary libor $3 \mathrm{M}$ rates and Turkish participatory banks deposits. Between the lag period of 1 and 12 , libor3M rates are more successful than CPI rates to forecast Turkish participatory banks deposits. In addition, between the lag rates of 1 to 12 , libor $3 \mathrm{M}$ can predict Turkish participatory banks deposits better than London gold prices prediction and London gold prices can predict Turkish participatory banks deposits better than Turkey's Customer Price Index data prediction. Table V, Table VI, Table VII indicates Granger causality test results. Table V shows the Granger causality relations between stationary 3 Month Libor rates and Turkish participatory banks deposits. Table VI shows Granger causality relationship between detrended London gold prices and Turkish participatory banks total deposits. Table VII shows Granger causality relationship between Turkey's detrended Customer Price Indexes and Turkish participatory banks deposits. Granger causality tests were done within the constraint of $\% 90$ confidence interval. 
Moreover, in Fig. 3. Since dots are inside the circle, vector autoregressive modeling can be done.

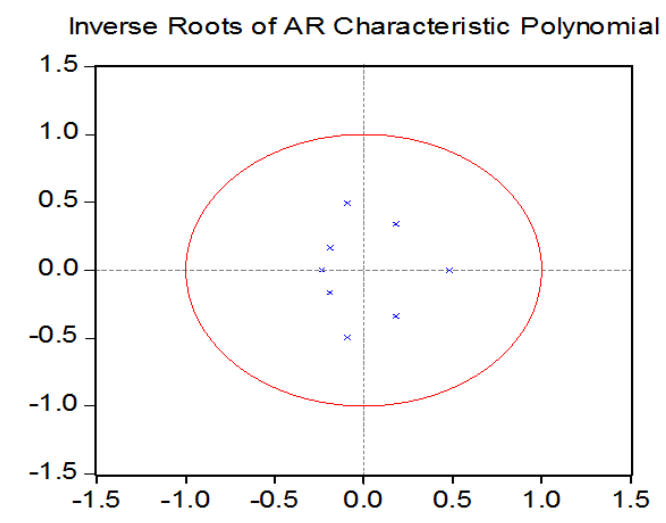

Fig. 3. AR characteristic polynomial test.

TABLE V: GRANGER CAUSALITY TEST BETWEEN LIBOR3M1 AND DEPOSITS 1 - P VALUE

\begin{tabular}{|l|l|}
\hline Lag1 & $0.06^{* *}$ \\
\hline Lag2 & $0.02^{*}$ \\
\hline Lag3 & $0.03^{*}$ \\
\hline Lag4 & $0.00^{*}$ \\
\hline Lag5 & $0.00^{*}$ \\
\hline Lag6 & $0.00^{*}$ \\
\hline Lag7 & $0.00^{*}$ \\
\hline Lag8 & $0.00^{*}$ \\
\hline Lag9 & $0.01^{*}$ \\
\hline Lag10 & $0.01^{*}$ \\
\hline Lag11 & $0.03^{*}$ \\
\hline Lag12 & $0.08^{*}$ \\
\hline
\end{tabular}

*Indicates $\mathrm{p}$ value is less than 0.05

** Indicates p value is less than 0.10

TABLE VI: GRANGER CAUSALITy TEST BETWEEN GOLD PRICES1 AND DEPOSITS $1-\mathrm{P}$ VALUE

\begin{tabular}{|l|l|}
\hline Lag1 & 0.0 * $^{*}$ \\
\hline Lag2 & $0.03^{*}$ \\
\hline Lag3 & $0.06^{* *}$ \\
\hline Lag4 & 0.12 \\
\hline Lag5 & 0.51 \\
\hline Lag6 & 0.41 \\
\hline Lag7 & 0.57 \\
\hline Lag8 & 0.55 \\
\hline Lag9 & 0.31 \\
\hline Lag10 & $0.03 *$ \\
\hline Lag11 & $0.06 * *$ \\
\hline Lag12 & 0.17 \\
\hline Indicates p value is less than 0.05 \\
\hline
\end{tabular}

**Indicates $\mathrm{p}$ value is less than 0.10

Between the lag period of 1 and 2, Schwarz information criteria had minimum negative value in unrestricted VAR test. Then vector error correction test applied. It was unearthed that first lagged and second lagged coefficients of 3 Month libor rates had negative adjustment effect on Turkish participatory banks deposits for long term equilibrium relationship. Nevertheless, Table VIII indicates that Turkey's
Customer Price Index rates with first and second lagged coefficients have positive impact on long term equilibrium relationship which means Turkey's Customer Price Index rates do not have impact for converting the location of Turkish participatory banks deposits to equilibrium point.

TABLE VII: GRANGER CAUSALITY TEST BETWEEN CPI 1 AND DEPOSITS 1 P VALUE

\begin{tabular}{|l|l|}
\hline Lag1 & 0.51 \\
\hline Lag2 & 0.61 \\
\hline Lag3 & 0.19 \\
\hline Lag4 & 0.36 \\
\hline Lag5 & 0.37 \\
\hline Lag6 & 0.40 \\
\hline Lag7 & 0.56 \\
\hline Lag8 & 0.55 \\
\hline Lag9 & 0.54 \\
\hline Lag10 & 0.53 \\
\hline Lag11 & 0.58 \\
\hline Lag12 & 0.70 \\
\hline - Null hypotheses were failed to reject.
\end{tabular}

TABLE VIII: VECTOR ERROR CORRECTION MODEL — INDEPENDENT VARIABLES COEFFICIENTS

\begin{tabular}{|l|l|}
\hline $\mathrm{D}($ DEPOSITS(-1)) & -0.13 \\
\hline $\mathrm{D}(\mathrm{DEPOSITS}(-2))$ & -0.09 \\
\hline $\mathrm{D}($ LIBOR3M(-1)) & -0.006369 \\
\hline $\mathrm{D}($ LIBOR3M(-2)) & -0.011763 \\
\hline $\mathrm{D}($ Gold(-1)) & 0.13 \\
\hline $\mathrm{D}($ Gold(-2)) & 0.013896 \\
\hline $\mathrm{D}(\mathrm{CPI}(-1))$ & 0.02 \\
\hline $\mathrm{D}(\mathrm{CPI}(-2))$ & 0.06 \\
\hline $\mathrm{C}$ & 0.02 \\
\hline $\begin{array}{l}\text { Dependent Variable: D(DEPOSITS) } \\
\text { R squared: (0.201282) }\end{array}$
\end{tabular}

\section{CONCLUSION}

It has been found that between the period of December 2005 and November 2013, 3 Month Libor rates, London gold prices and Turkey's Customer Price Index rates do not have significant impact on Turkish participatory banks total deposits. Nevertheless, there is long term equilibrium relationship between stationary variables. Between the lag rates of 1 to 12, there are unidirectional relationships between stationary 3 Month Libor rates and Turkish participatory banks deposits. Moreover, first lag value of Turkish participatory banks deposits has significant effect on Turkish participatory banks deposits. According to variance decomposition analysis and impulse response analysis, libor 3M innovation impact is more than Turkey's Customer Price Index rates and London gold prices to explain the variance of Turkish participatory banks deposits. In addition, vector error correction model supports Granger causality test and first and second lag of 3 Month Libor rates have negative adjustment effect on Turkish's participatory banks deposits in vector error correction model. First and second lag of Customer Price Index does not have negative adjustment effect on Turkish participatory banks deposits. Research result corresponds with the indication of cointegrating relationship between the rates of return on PLS(Profit and Loss Sharing) accounts and conventional bank deposit rates in both 
Malaysia and Turkey [2]. Research result has also similarity with the findings which indicated that retail participatory banks follow conventional banks deposit rates in Malaysia [16]. It can be indicated that the more libor rates decline the more participatory banks have to collect deposits. Turkish participatory banks treasury departments should analyze 3 Month Libor rates and make forecast of future libor rates. It is likely that 3 Month Libor rates can decline more and Turkish participatory banks will need to collect more deposits from customers. Those deposits can be in the form of gold savings, more integration with businesses for the services of Profit and Loss Sharing(PLS).According to participatory banks principles, there is no interest rate transaction on money. Given the 3 Month Libor rates, since in the future, more deposits will be needed, Turkish participatory banks need to create more venture capital investment credits. As conventional counterparts, Turkish participatory banks should not limit business life to one year for business credit and assist entrepreneurship process in Turkey. With that strategy, more sustainable businesses can be created and when those businesses are profitable, Turkish participatory banks can collect more deposits from those businesses and use those business deposits accounts for another businesses needs. Turkish participatory banks should engage in private equity transactions and open new companies with entrepreneurs. If infant company can be successful, Turkish participatory banks can sell their shares at premium and leave entrepreneurs as main shareholder. After Turkish participatory banks increase their deposits with investment activities, they can support infant industries more. In addition, with diminishing rates of Libor3M costs, businessman can borrow money with less cost by international finance operations and use that money for international and local operations such as investments to manufacturing facilities, real estate, oil, logistics sectors, and private equity transactions. After they have huge profits from investments, they can put more deposits into Turkish participatory banks.

\section{ACKNOWLEDGMENT}

I would like to thank to editors who evaluated my article.

\section{REFERENCES}

[1] U. T. Aburime and F. Alio, "Islamic banking: theories, practices and insights for Nigeria," International Review of Business Research Papers, vol. 5, no. 1, pp. 321-339, 2009.

[2] S. Cevik and J. Charap, "The behaviour of conventional and Islamic bank deposit returns in Malaysia and Turkey," IMF Working Paper WP/11/156, July 2011.
[3] P. Imam and K. Kpodar, "Islamic banking: how has it diffused?" IMF Working Paper WP/10/195, August 2010.

[4] A. G. F. Hoepner, H. G. Rammal, and M. Rezec, "Islamic mutual fund's financial performance and international investment style: Evidence from 20 countries," European Journal of Finance, vol. 17 no. 9-10, March 2011.

[5] T. S. Zaher and M. K. Hassan, "A Comparative Literature Survey of Islamic Finance and Banking," Financial Markets, Instutions, Instruments, vol. 10, no. 4, pp. 155-199, 2001.

[6] F. Khan, "How 'Islamic' is Islamic banking?" Journal of Economic Behavior \& Organization, vol. 76 , pp. 805-820, December 2010.

[7] T. Beck, A. D. Kunt, and O. Merrouche, "Islamic vs. conventional banking: Business model, efficiency and stability," Journal of Banking\& Finance, vol. 37, no. 2 , pp. 433-447, February 2013.

[8] T. Beck, A. D. Kunt, and O. Merrouche, "Islamic vs. conventional banking business model, efficiency and stability, policy," World Bank Policy Research Working Paper 5446, August 2010.

[9] T. Adrian and H. S. Shin, "Liquidity and financial contagion," Banque de France Financial Stability Review, no. 11, February 2008.

[10] J. C. Rochet and J. Tirole, "Interbank lending and systemic risk," Journal of Money, Credit and Banking, vol. 28, no. 4, pp. 733-762, November 1996

[11] A. M. Santomero, "Commercial bank risk management: an analysis of the process," Wharton University Working Paper Series 95-11-C, 1997.

[12] P. Molyneux and J. Thornton, "Determinants of European bank profitability: A note," Journal of Banking and Finance, vol. 6, no. 16, pp. 1173-1178, 1992.

[13] P. Bourke, "Concentration and other determinants of bank profitability in Europe, North America and Australia," Journal of Banking\& Finance, vol. 13, no. 1, pp. 65-79, March 1989.

[14] A. D. Kunt and H. Huizanga, "Financial structure and bank profitability," World Bank Policy Research Working Paper, January 2000 .

[15] J. A. Bikker and H. Hu, "Cyclical patterns in profits , provisioning and lending of banks and procyclicality of the new Basel capital requirements," Psl Quarterly Review, vol. 55, no. 221, pp. 143-175, 2002.

[16] B. S. Chong and M. H. Liu, "Islamic banking: Interest-free or interest based," Pacific-Basin Finance Journal, vol. 17, no. 1, pp. 125-144, January 2009.

[17] E. H. Ergeç and B. G. Arslan, "Impact of interest on Islamic and conventional banks: the case of Turkey," Applied Economics, vol. 45, no. 17 , pp. $2381-2388,2013$.

Hüseyin Çetin was born on April 12, 1986. He received his bachelor of management degree at Sabancı University, Turkey in January 2010, and his master of international business degree at Griffith University, Australia, in September 2010. He is currently enrolled in PhD. business administration programme at Okan University Social Science Institute, Turkey.

$\mathrm{He}$ is currently working part time at Irmak Src firm as a logistics lecturer. $\mathrm{He}$ is teaching to logistic sector employees, high and middle level managers for logistics sector adequacy examination. He is currently writing book for high and middle level managers who prepare for logistic sector adequacy examination.

Hüseyin Çetin's research interest is in finance, banking and international economics. He has published articles about banking and international economics. In addition, he attended to finance and mathematics conferences. 